\title{
Gamonales y alcaldes: poder institucional y parainstitucional en la Primera Violencia (Colombia, 1930-1934)*
}

\author{
por \\ María del Rosario Vázquez Piñeros ${ }^{1}$ \\ Universidad de La Sabana, Chía (Colombia)
}

A partir de la consulta y el cotejo de fuentes documentales y hemerográficas, civiles y eclesiásticas, el presente artículo analiza la relación de los gamonales y las autoridades civiles locales con grupos armados institucionales y parainstitucionales, los cuales, mediante el ejercicio de la coacción y la persecución, sirvieron como instrumentos para lograr el triunfo electoral de sus partidos políticos. Esta relación convirtió a dichos actores en artífices de primer orden de la fase inicial de la violencia liberal-conservadora, que empezó bajo el gobierno del presidente colombiano Enrique Olaya Herrera (1930-34).

Palabras Clave: Colombia; violencia; administración local; elecciones; fuerzas armadas.

Cómo citar este artículo / Citation: Vázquez Piñeros, María del Rosario, "Gamonales y alcaldes: Poder institucional y parainstitucional en la Primera Violencia (Colombia, 19301934)", Revista de Indias, LXXVII/269 (Madrid, 2017): 305-334, doi:10.3989/revindias.2017.010.

* El presente artículo ha sido elaborado en el marco del proyecto de investigación La relación entre política y religión: un examen de la filosofía política desde la primera modernidad hasta la postmodernidad, financiado por la Facultad de Filosofía y Ciencias Humanas y la Dirección de Investigación de la Universidad de La Sabana (HUM-48-2012).

1 maria.vasquez@unisabana.edu.co ORCID iD: http://orcid.org/0000-0002-7583-7695.

El artículo presenta un análisis del conflicto entre tradición y modernidad, en Colombia. Ha sido elaborado en el marco de un proyecto de investigación y a partir de la tesis doctoral de la autora. Cfr. Vázquez Piñeros, 2012: 127-165. 


\section{INTRODUCCIÓN}

La presente investigación tiene como principal objetivo recalcar el importante papel de los gamonales ${ }^{2}$ y autoridades civiles locales en la violencia bipartidista de la década del treinta del siglo XX, en la región nororiental de Colombia (departamentos de Santander del Norte, Santander del Sur y Boyacá), como agentes encargados de garantizar el triunfo electoral de su partido, mediante el ejercicio de la coacción y la persecución a sus oponentes políticos, a través de la politización de la policía, la creación de policías cívicas como brazos armados de los caciques, el apoyo a bandoleros de su propia colectividad, el enfrentamiento con el ejército - en cuanto este cuerpo mostró conductas menos sectarias-; y en la medida en que el uso ilegítimo del poder del Estado provocó el surgimiento de las autodefensas, como reacción a la persecución oficial. Con este fin, se consultó la bibliografía existente sobre el conflicto liberal-conservador y el papel de la fuerza pública como actor esencial en estos hechos durante este período. Asimismo, proporcionan luces los estudios relativos a este mismo fenómeno -en diferentes etapas y en otros espacios de España y América-, con similitudes políticas y socioculturales; y, desde luego, se tuvieron en cuenta interpretaciones acerca del rol de los gamonales en el panorama político de la democracia colombiana, desde sus albores en el siglo XIX. A todos ellos haremos referencia en su debido momento. En todo caso, con el fin de ampliar las explicaciones existentes, se consultaron fuentes documentales, así como también hemerográficas ${ }^{3}$, correspondientes al gobierno de la Concentración Nacional (1930-1934), en las Bibliotecas Nacional de Colombia y Luis Ángel Arango; y en el Archivo General de la Nación, el Archivo de la Arquidiócesis de Pamplona y el Archivo Secreto Vaticano.

\section{La Primera Violencia: Se Desata el CONFLicto biPARTidista}

En agosto de 1930, el liberal Enrique Olaya Herrera se posesionó como presidente de Colombia, con un programa de Concentración Nacional, a través

2 El término «gamonalismo» corresponde, en América Latina, a lo que en España se entiende como «caciquismo», esto es, el funcionamiento del sistema político-social propio de la Restauración (1875-1931), reflejado en las formas de poder y privilegios que se daban a nivel local. Sus antecedentes son rastreables en los siglos anteriores, bajo el absolutismo monárquico, en escenarios rurales donde permanecían arraigados rezagos del feudalismo. Un análisis y tipificación clásica de este fenómeno en España, en Costa, 2012.

3 Reflexiones sobre la prensa como fuente documental para investigar el conflicto bipartidista colombiano, en Vázquez Piñeros, 2007: 330-332. 
del cual invitó a los conservadores a participar en el gobierno. No obstante estos últimos habían permanecido en el poder durante cuarenta y cinco años, y a pesar de los antecedentes de continuas guerras entre liberales y conservadores a lo largo del convulso siglo XIX, el traspaso se hizo de forma pacífica, o al menos así ocurrió en la capital de la república. No queda la menor duda de la incuestionable habilidad del primer mandatario para mantener un equilibrio de intereses, en la media en que los nombramientos en el gabinete ministerial incluyeron a personajes de los partidos tradicionales, representantes de distintas regiones, facciones políticas y grupos económicos. Lo mismo ocurrió con las gobernaciones y demás instancias del poder público 4 .

Aunque el manejo diplomático y consensual de Olaya en principio tuvo éxito en las altas esferas de la política nacional, esto no impidió que se desatara un enfrentamiento entre liberales y conservadores en algunas zonas predominantemente rurales del país. Por esta razón, desde 1932, el político conservador Laureano Gómez atacó desde la tribuna pública al presidente, al que acusó de ser el responsable de los brotes y la extensión de la violencia. En todo caso, cuando en concordancia con los acuerdos de la Concentración el gobierno llevó a cabo el correspondiente reemplazo de gobernadores y alcaldes, estos cambios no siempre fueron bien recibidos por las mayorías conservadoras, $\mathrm{y}$, por lo demás, suscitaron entre los liberales expectativas revanchistas. Hay que recordar que, en este contexto $-\mathrm{y}$ en concordancia con la centralista Constitución de 1886- el Presidente de la República ejercía la facultad de nombrar a los gobernadores (siete conservadores y siete liberales) $)^{5}$, y estos a los alcaldes, quienes a su vez elegían al personal bajo sus órdenes ${ }^{6}$.

De esta forma, los nuevos gobernadores liberales tuvieron entre sus principales objetivos hacer posible el triunfo de su partido en aquellas poblaciones en donde eran mayoría, y en las que, a su vez, habían sido víctimas del fraude sistemático durante la hegemonía conservadora. Puesto que el conservatismo, al menos hasta entonces, contaba todavía con la mayoría de sufragantes

${ }^{4}$ Abel, 1987: 102 y 103. Giobbe a Pacelli, 19 de diciembre de 1930, Archivo Secreto Vaticano, Roma (ASV), Archivo de la Segunda Sección de la Secretaría de Estado, Relaciones con los Estados (AES), Colombia, pos. 566, fasc. 29, fol. 21r.

5 En cuanto a los conservadores nombrados en las gobernaciones, al no prestarse a tales concesiones, eran reemplazados por otros más condescendientes. De todas formas, Abadía, en los últimos meses de su gobierno, había conformado un gabinete con las mismas características y proporciones. Giobbe a Pacelli, 7 de septiembre de 1930, ibidem, fols. 07r y 07v. Es de notar que Olaya entregó al liberal Celso Rodríguez la gobernación del entonces mayoritariamente conservador departamento de Boyacá. Guerrero, 2007: 91.

6 Quintero, 2008: 246. 
del país, las autoridades liberales tuvieron a su cargo una política de «liberalización forzada», con el apoyo de los cuerpos de policía. Esto precipitó la reacción conservadora y una guerra regional en Santander, Norte de Santander y Boyacá 7 y, en menor medida, en Tolima y Cundinamarca. El historiador Javier Guerrero denominó Primera Violencia a este proceso de origen local y regional que dio como resultado lo que calificó como un fenómeno «parainstitucional», en el cual los partidos invadieron las funciones del Estado en lo político, administrativo, policivo y judicial ${ }^{8}$. Es necesario recordar que para lograr la hegemonía, era indispensable que el liberalismo obtuviera el control de las burocracias municipales, articuladas a su vez a los andamiajes de los directorios departamentales y nacionales ${ }^{9}$.

En este contexto, las mayorías políticas de uno y otro bando, en cada localidad, expulsaron a sus oponentes y se apoderaron de sus propiedades, dándose el caso «de no quedar en ciertos puntos sino elementos de un solo partido» ${ }^{10}$; mientras que simultáneamente se cometían los más atroces asesinatos, individuales y colectivos, bajo la más absoluta impunidad ${ }^{11}$. Un memorando correspondiente a este período, explica las causas de la violencia: el cambio de gobierno, el matonismo, la falta de horizontes como resultado del aislamiento geográfico, las manipulaciones orquestadas desde las capitales y la intromisión política del clero ${ }^{12}$.

7 Es importante recordar que la Guerra de los Mil Días (1899-1902), la última y la más sangrienta del siglo XIX colombiano, tuvo como uno de sus principales escenarios las regiones objeto de estudio en el presente artículo.

8 Guerrero, 2007: 30, 31 y 45. Según Paul Oquist, en la medida en que el Estado colombiano fue ganando terreno como facilitador del desarrollo capitalista, y en que a su vez aumentaron los mecanismos intervencionistas, también se agudizaron las pugnas bipartidistas por alcanzar su control. El resultado de todo ello fue el progresivo quiebre de las instituciones, en tanto buena parte de las autoridades ejercieron su poder y administraron la justica, a partir de criterios sectarios, lo que significó -según el autor- un «derrumbe parcial del Estado». Oquist, 1978: 244, 245 y 255-269.

9 Guerrero, 2007: 58 y 59.

10 Memorándum sobre situación de los dos Santanderes, Archivo General de la Nación, Bogotá (AGN), Archivo Anexo 2 (AA2), Ministerio de Gobierno (MG), sección 4 (S4ta), Justicia, Orden Público-Informes, caja 1, carpeta 3, fol. 80.

11 Se refiere a las «prácticas punitivas», es decir, a la forma como las autoridades ejercían un control social informal y parainstitucional, mediante la represión, la persecución y el homicidio. Quintero, 2008: 245-257.

12 Memorándum sobre situación de los dos Santanderes, AGN, AA2, MG, S4ta, Justicia, Orden Público-Informes, caja 1, carpeta 3, fol. 80. Sobre el papel del clero en política, en la región nororiental del país, cfr. Cáceres, 2013: 187-127. Calderón, 2013: 157-185. Vázquez Piñeros, 2014b. 
En el caso de la región estudiada, existe abundante documentación acerca de las múltiples denuncias en contra de las autoridades locales de los dos bandos, especialmente alcaldes y en algunos casos jueces, así como de la policía municipal, departamental y, en menor media, también de la nacional. Autoridades que con contadas excepciones, actuaron bajo criterios sectarios, mientras cometían graves atropellos en contra de la población que no pertenecía a su partido ${ }^{13}$. Hay que anotar que en algunos municipios donde se mantuvieron alcaldes y, o jueces conservadores, los liberales presentaron exactamente las mismas quejas ${ }^{14}$. Por ejemplo, liberales de Chita, en el departamento de Boyacá, le escribieron al entonces representante a la Cámara, Plinio Mendoza Neira, solicitando garantías para sus copartidarios, y para «impedir que personas y bienes liberales sigan siendo víctimas; que gobierno envíe investigador porque al ser confiada investigación a autoridades comparsas asesinos, quedaríase asesinato como tantos con horrendo manto impunidad» ${ }^{15}$.

En general, prevaleció la idea de que los abusos ocurrían a espaldas del Gobierno Nacional. Sin embargo, Laureano Gómez insistió en la responsabilidad directa de Olaya al permitir la impunidad de los crímenes cometidos contra los conservadores ${ }^{16}$. Efectivamente, la mayoría de los integrantes de este partido denunciaron la complicidad de los gobiernos municipales con los departamentales; y la sospecha de que los alcaldes y policías sectarios actuaban con la aprobación de sus superiores en las gobernaciones. Sin embargo, casi todos coincidieron -con algunas excepciones, como Gómez- en reconocer las buenas intenciones del gobierno de la Concentración, comenzando por el presidente y sus ministros, aunque era difícil explicar las razones por las cuales el ejecutivo central, no siempre destituía a quienes desobedecían sus órdenes, o se demoraba en efectuar las necesarias remociones ${ }^{17}$.

13 El Nuevo Tiempo, Bogotá, 29 de octubre de 1930: 1; 1 de enero de 1931: 1 y 8; 11 de diciembre de 1930: 1: "Denuncias del miembro del Directorio Conservador de Santander, Serrano Blanco".

14 El Tiempo, Bogotá, 1 de junio de 1933: 6.

15 Buitrago y Ojeda a Mendoza, 12 de julio de 1932, AGN, AA2, MG, S4ta, Justicia, Orden Público-Informes, caja 1, carpeta 4, fols. 107 y 108. Sobre este tema, ver también: Vázquez Piñeros, 2014b: 266.

16 Gómez, 1934. Acusaciones sobre este particular efectuó el sacerdote Daniel Jordán, cfr. El Tiempo, Bogotá, 11 de agosto de 1934: 6.

17 Como ocurrió, por ejemplo, con el gobernador de Boyacá, Celso Rodríguez, acusado de no impedir un ataque a los conservadores a manos de la policía liberal. Giobbe a Pacelli, 29 de diciembre de 1930, ASV, AES, Colombia, pos. 566, fasc. 29, fol. 21r. El Cardenal Pacelli, Secretario de Estado de la Santa Sede, sería el futuro Pío XII. 
Lo cierto es que los gobernadores, al ser nombrados por el ejecutivo nacional, al menos teóricamente debían estar comprometidos con la política de la Concentración. Por otra parte, los candidatos para las alcaldías eran elegidos por los gobernadores, y en muchos casos sugeridos por los directorios departamentales de los partidos, bajo criterios fundamentalmente oportunistas, puesto que su interés era el de manipular el poder local en aras del beneficio electoral y clientelista de su colectividad, en las provincias. En esa medida, dichos alcaldes constituyeron, seguramente, una de las instancias más directamente responsable de la violencia, como consta en un comentario sobre el municipio de Arboledas (Norte de Santander), según el cual, el gobernador Luis Augusto Cuervo - conservador- al parecer de algunos, no tenía noticia de los abusos de sus subalternos: «Le han tocado a este municipio los peores alcaldes del régimen, no propiamente por culpa del Señor Gobernador, que es desconocedor de los planes que se hacen a sus espaldas en la escogencia de los candidatos por parte de las directivas liberales» ${ }^{18}$.

Sin embargo, esta apreciación sobre la responsabilidad de los gobernadores podría resultar demasiado benévola, si se tiene en cuenta que no siempre dieron crédito suficiente a las denuncias de sus propios copartidarios; o por el contrario, hacían la vista gorda cuando eran estos quienes cometían los crímenes, tal vez con la excusa de que lo hacían en defensa propia. Sin lugar a dudas, este es un aspecto que merecería una investigación más amplia si se cotejan, por ejemplo, informes como el remitido por la Policía Nacional (pro-liberal) al Ministro de Gobierno, en el que se describe la actitud del gobernador Cuervo, acusado de mostrarse cómplice de los crímenes efectuados por sus copartidarios conservadores ${ }^{19}$; al tiempo en que era visto por algunos de ellos, como un líder condescendiente con los excesos del liberalismo.

Por su parte, el gobernador liberal Alejandro Galvis hizo lo propio para favorecer a su partido en Santander. Galvis había denunciado con anterioridad los reiterados fraudes conservadores, que impedían el triunfo de los liberales en pueblos donde -según afirmaba- contaban con reconocidas mayorías, como era el caso de aquellos ubicados en la región de García Rovira ${ }^{20}$. Por consiguiente, procedió al nombramiento de alcaldes liberales y al inmediato reemplazo de la policía conservadora. Con estos mecanismos, el gobernador

18 Romero a Morales, 16 de enero de 1933, AGN, AA2, MG, S4ta, Justicia, Orden Público-Informes, caja 1, carpeta 3, fol. 190.

19 Gómez a Morales, 9 de diciembre de 1932, ibidem, fol. 109.

20 La región de García Rovira abarca un espacio geográfico sumamente quebrado, en donde se desató la Primera Violencia; incluye territorios del departamento de Santander del Sur y sus límites con Boyacá. Guerrero, 2007: 49 y 50. 
garantizaría el triunfo de su partido, obstruido dolosamente, por más de cuatro décadas ${ }^{21}$.

Dentro de este entramado de clientelas partidistas es indispensable destacar el rol de los caciques o gamonales, cabezas de la política local y regional. François-Xavier Guerra encuentra en estos actores el elemento articulador entre las formas modernas de la nueva política electoral y partidista, y las realidades culturales y sociales heredadas del Antiguo Régimen ${ }^{22}$. Por su parte, Marco Palacios también hace referencia a un «bipartidismo caciquil», para explicar la forma como el tipo de poder local constituido desde el siglo XVIII, en manos de jefes con sus respectivas clientelas, a partir del XIX se adaptó a la nueva dinámica de los partidos, arrastrando tras de sí a los fieles seguidores. En la medida en que a diferencia de otros países de Amé-

${ }^{21}$ Incidentes violentos durante las elecciones para la Asamblea Departamental, hicieron que Alejandro Galvis renunciara a la gobernación; lo sucedió en el cargo el liberal Eduardo Santos. Henderson, 2006: 268, 269 y 271. Según el Nuncio, las elecciones para Asambleas Departamentales dejaron un saldo de muchos muertos y heridos, mientras los liberales mostraron un comportamiento «bárbaro». Giobbe a Pacelli, 5 de febrero de 1931, ASV, AES, Colombia, pos. 566, fasc. 29, fol. 27r.

22 Según explica Guerra, la figura del cacique nace en la época de las revoluciones liberales y, en el caso de Hispanoamérica, tras las independencias; por lo tanto, se trata de un actor propio de la cultura política moderna. Con la legitimación del Nuevo Régimen, se presentó la paradoja de una «modernidad política precoz y radical», prácticamente sobrepuesta en sociedades que mantenían muchos de sus rasgos tradicionales. Es entonces cuando, ante la debilidad de los nuevos Estados, se impusieron en los ámbitos locales, aquellos tipos de autoridades que provenían de la realidad sociocultural precedente. De esta forma, continúa el autor, la autoridad pasó a ser, como en la Alta Edad Media, más «personal» que nunca, en la medida en que reflejaba el control y la protección que ejercían los poderosos sobre la población que se encontraba bajo su injerencia. En este contexto, las élites gobernantes modernas debieron recurrir a los vínculos tradicionales, y los caciques se constituyeron, precisamente, en los necesarios intermediarios que conectaban los planteamientos y prácticas políticas modernas, con la realidad de un mundo social que pocas variaciones había sufrido en sus usos y costumbres, a pesar de las convulsiones revolucionarias que habían acabado con el absolutismo. Ahora bien, con la permanencia de una concepción de la sociedad que Guerra denomina «unanimista», los partidos eran vistos con acentuada desconfianza, al considerar que amenazaban la anhelada unidad del cuerpo social: por consiguiente, cualquier medio era aceptable, con tal de lograr la exclusión de los adversarios, y en esta tarea -podemos añadir- los caciques también desempeñaron una labor esencial. Guerra, 2012: 92-93 y 97-103. Sobre las raíces prehispánicas y coloniales del caciquismo, como principio de poder personalista, resultado de la dispersión geográfica y demográfica, así como de la cultura patriarcal -con sus correspondientes lealtades familiares, territoriales y de patronazgos, reticentes a la intromisión del Estado moderno en los asuntos locales-, y su evolución en el México urbano e industrializado, en la segunda mitad del siglo XX, ver: Buve, 2003: 19-39. Y acerca de la permanencia del caciquismo como cultura política, a pesar de los cambios de régimen monárquico, republicano y nacionalista, en España, cfr. Rodríguez y Cazorla, 2008: 471-502. 
rica Latina, los caudillos colombianos - como Mosquera y Obando, por ejemplo-, no lograron consolidar un poder estable y unificado -al estilo de Santa Ana o Rosas-, debieron asumir, entonces, su manifiesta debilidad y ganar el apoyo de las bases municipales, entablando prácticas de coalición y concertación que el profesor Palacios denomina como «civilismo caciquil». Cabe agregar, para la comprensión del tema que nos ocupa, que en este ambiente, entre 1918 y 1948, «las instituciones de un capitalismo en plena expansión eran demasiado débiles y las movilizaciones electorales, demasiado conflictivas» ${ }^{23}$.

En este orden de ideas, hay que subrayar que en la medida en que desde el siglo XIX, los gamonales tuvieron a su cargo el levantamiento de levas para las guerras y la obtención de electores, desempeñaron un papel esencial en el andamiaje clientelista; y mucho más cuando se iba extendiendo el derecho al voto ${ }^{24}$. Dado el atraso del país y de las comunicaciones, la desarticulación geográfica y las costumbres políticas heredadas, aquellos llegaron a disfrutar de una gran autonomía frente a sus respectivos jefes políticos y, por lo tanto, pudieron mantener cierta distancia respecto de las alianzas bipartidistas y los estilos moderados establecidos en Bogotá, como era el caso del programa de la Concentración. Así, en estas condiciones, los principales jefes de los partidos ejercieron una injerencia relativa sobre la población rural, que para entonces constituía la mayor parte del país ${ }^{25}$. Sin embargo, tampoco se podría negar el apoyo subrepticio de dichos jefes nacionales a las prácticas inescrupulosas de los caciques; o, por lo menos, que no tomaran medidas suficientemente severas en contra de ellas, seguramente tras sopesar los dividendos electorales y el poder que les reportaban. Por lo tanto, no dejan de resultar ilustrativas las palabras de un miembro conservador del Consejo Electoral de Boyacá, sobre el rol de los caciques de su propia colectividad, quie-

23 Palacios, 1996: 9, 10 y 15.

${ }^{24}$ La reforma constitucional de 1910, introdujo el voto directo para presidente, aunque restringido a los alfabetos, o que contaran con una renta anual de 300 pesos, o propiedades equivalentes a 1.000 pesos. Eduardo Posada presentó un análisis sobre las prácticas electorales y su relación con la violencia, en Colombia durante el siglo XIX, en el que además comparó dicha situación con lo sucedido en circunstancias similares, en otros países como Inglaterra. Posada, 2003: 237 y 238.

25 Sobre la figura del cacique y su poder efectivo en México, antes y después de la Independencia, vale la pena retomar la siguiente descripción: «Este hombre, pues, fue el que en el anterior sistema compraba sus favores, servicios y dinero a los subdelegados para administrar justicia a su contento; éste, el que en el nuevo, forma las elecciones a su paladar; y éste, por último, el que antes, ahora y en todos los tiempos ha gobernado». Cfr. "Memorial Jueces de Letras", Ocampo, 1969: 204-206, cit., por Buve, 2003: 27. 
nes «durante 45 años corrompieron al partido conservador y condujeron al pueblo y a la juventud como bestias, en beneficio personal», razón por la cual proponía «hacer respetar la ley y sancionar a los conductores ineptos del conservatismo» ${ }^{26}$.

En este orden de ideas, el historiador Jorge Orlando Melo describió los diversos estilos de gamonales, ya se tratara de «jefes pueblerinos» o de «grandes caciques regionales»; algunos ricos, otros tan solo agentes de propietarios; en unos casos explotadores de los campesinos, en otras ocasiones defensores de los mismos, «dueños de vidas y haciendas o simples dueños de votos» ${ }^{27}$. En la medida en que la participación ciudadana fue en aumento, con la ampliación del sufragio, los gamonales no tuvieron otra alternativa que adoptar nuevas estrategias para movilizar a las masas campesinas que ahora podían ejercer el derecho al voto, lo que a su vez implicaba propiciar un ambiente de «entusiasmo e identidad de partido (a veces mediante la promoción de la confrontación violenta con el adversario), de incrementar la participación política» ${ }^{28}$.

Es, por tanto, indispensable subrayar el papel central desempeñado por los caciques o gamonales como gestores y artífices de la violencia bipartidista. El historiador inglés Malcom Deas, hizo un análisis del poder y las características de este grupo social, más concretamente de los gamonales de adscripción local, a partir de una descripción sobre el tema -relativa a las circunscripciones cercanas a la capital del país- y efectuada por el inspector del gobierno Rufino Gutiérrez, autor de unas Monografías, escritas después del período de la Regeneración ${ }^{29}$. Según Gutiérrez, los dueños de las grandes haciendas que vivían en las ciudades - en este caso Bogotá- procuraban mantener distancia de los asuntos de la política local; pero, a su vez, respaldaban el nombramiento de alcaldes y demás autoridades provenientes de la clase media campesina, compuesta, principalmente, por propietarios menores. Este sector de la sociedad rural presentaba las siguientes características: su origen racial podía ser blanco, mestizo o indígena, y aunque en su mayoría se tratara de «familias ejemplares», también había individuos corruptos, algunos de ellos dedicados a la política, es decir, gamonales o caciques, «gente despiadada, que esquilma a los infelices indios y abusa de ellos sin misericordia». De tal forma que es precisamente de este grupo «ignorante» y con «escasas nociones de moral», de donde salían a menudo las autoridades municipales.

\footnotetext{
${ }^{26}$ El Tiempo, Bogotá, 8 de julio de 1933: 1.

27 Melo, 1998: 4 y 5.

28 Idem.

29 Gutiérrez, 1920: 90-92. Citado en Deas, 2006: 209-233; 1973: 118-140.
} 
En estas condiciones, jueces y alcaldes ejercían el poder en beneficio de sus parientes y allegados políticos, y con frecuencia en detrimento de los más pobres. Gutiérrez describe la idiosincrasia de este sector, en cuyas manos quedaba el poder a nivel local, como una «clase llena de envidia de las comodidades de que disfrutaban los grandes hacendados y de desprecio hacia sus inferiores», de la cual surgían, de cuando en cuando, «notables soldados y jefes tan abnegados como entusiastas $\rangle^{30}$.

Seguramente, tal como afirma Deas, cuanto más provinciano fuera un terrateniente, probablemente era menos rico, menos influyente a nivel nacional $\mathrm{y}$, por consiguiente, más gamonal ${ }^{31} ; \mathrm{y}$, podríamos agregar, menos citadino y más rural en sus usos y costumbres, es decir, más próximo, desde el punto de vista sociológico al tipo de relaciones de poder premodernas, todavía existentes en el campo. En la práctica, esta era también la base real sobre la cual funcionaba un sistema ideal y parcialmente democrático, en la mayor parte del país, en los años treinta. Los relatos acerca del comportamiento sectario, tosco y abusivo de los alcaldes en la Primera Violencia, y de la forma como competían en las frecuentísimas disputas electorales -a través de la movilización de unos votantes, dispuestos a perpetrar agresiones o defenderse de las de sus contrarios-, permiten vislumbrar perfiles muy cercanos a las descripciones hechas por Gutiérrez ${ }^{32}$, y también al análisis sobre este tipo de gamonales efectuado por los autores contemporáneos antes mencionados.

Por otra parte, es importante establecer la forma como se alinearon los grupos armados, institucionales y parainstitucionales, a partir de esta etapa que, como se ha dicho, marca el inicio de «la violencia»:

Del lado liberal estaban la policía, los guardias de rentas y grupos de civiles armados que acompañaban a los uniformados. Del conservador, sus respectivas policías cívicas ${ }^{33}$, los bandoleros políticos ${ }^{34}$, que contaban con el respaldo de los

30 Idem.

31 Deas, 2006: 230.

32 Sobre la relación de los poderes electorales locales con el engranaje de la política nacional, ver: Vázquez Piñeros, 2014a: 433-458.

33 Sánchez y Meertens, 2000: 20. Guerrero, 1991. Acuña, 2003: 311-312.

34 Una investigación pionera sobre el bandolerismo político correspondiente a la Violencia bajo los gobiernos conservadores (1946-58) y los primeros años del Frente Nacional (1958-74), en: Sánchez y Meertens, 2000: 25-28 y 42-61. Sin embargo, queda pendiente ampliar la investigación sobre el tema, con el fin de establecer las continuidades y rupturas de este fenómeno desde sus raíces antes, durante y después de la Hegemonía Liberal (193046). En todo caso, sobre la evolución del bandolerismo político a la mafia de las esmeraldas, en el Departamento de Boyacá, ver: Guerrero, 2008: 111-135. 
campesinos; y, por último, las autodefensas ${ }^{35}$, cuyos miembros eran tildados por las autoridades también de bandoleros, a pesar de que presentaban una organización y un número mayor de integrantes. El ejército mostró una posición más ecuánime, profesional y menos sectaria ${ }^{36}$, aunque, desde luego, encaminada prioritariamente a la represión de los conservadores alzados en $\operatorname{armas}^{37}$.

\section{EJÉRCITO VS. ALCALDES Y POLICÍAS}

En primer lugar, hay que resaltar el hecho de que la policía nacional dependiente en aquel entonces del Ministerio de Gobierno, sufrió un rápido proceso de liberalización, tras el ascenso de Olaya $^{38}$. Por otra parte, los alcaldes liberales, rodeados en principio por los conservadores reticentes a someterse al nuevo gobierno, crearon las ya mencionadas policías cívicas para contar con personal de confianza, especialmente en poblaciones de mayoría conservadora $^{39}$. Los conservadores, por su parte, hicieron lo mismo; primero, para resistirse a la entrega del control de la maquinaria electoral y de las instituciones; y luego, para defenderse de la persecución del liberalismo ${ }^{40}$.

En esta guerra civil no declarada, liberales y conservadores cometieron todo tipo de atropellos, y la policía actuó, con mucha frecuencia, bajo extremos grados de beodez ${ }^{41}$, lo que contribuyó en gran medida a que fueran más execrables sus excesos. El testimonio del campesino boyacense, Heraclio Cañón, quien posteriormente se dedicara a vengarse de los abusos cometidos contra su familia, ilustra las persecuciones y asesinatos a los que fue sometida la población por parte de la policía - enviada por un gamonal, Siervo Castro- y el revanchismo suscitado por este tipo de actuaciones ${ }^{42}$. Como era apenas de esperar, los agentes recibieron el natural rechazo por parte de los campesinos,

35 Cadena Dacosta a Olaya Herrera, 2 de julio de 1932, AGN, AA2, Ministerio de Gobierno, S4ta, Justicia, Orden Público-Informes, caja 1, carpeta 3, fol. 33. Alcalde de Capitanejo al Ministro de Gobierno, ibidem, fols. 34 y 35; Memorándum sobre la situación en los Santanderes ( $\sin$ fecha), ibidem, fol. 81. Acerca de la resistencia conservadora en la región de García Rovira durante los primeros años de la Hegemonía Liberal, ver: Guerrero, 1991: 158-163.

${ }^{36}$ Cfr. Acuña, 2006, 8: 111-116. Porras a Olaya Herrera, 15 de septiembre de 1932, AGN, AA2, Ministerio de Gobierno, S4ta, Justicia, Correspondencia-Telegramas, caja 3, carpeta 3, fol. 132.

37 Vázquez Piñeros, 2014b: 267.

38 Guerrero, 2007, nota 119: 107. El Nuevo Tiempo, Bogotá, 23 de enero de 1931: 1.

39 Sánchez y Meertens, 2000: 20, en Guerrero, 1991. Acuña, 2006.

40 Idem.

41 Guerrero, 2007: 94 y 95; 1991: 194.

42 Hilarión, 1953: 129. Citado en Henderson, 2006: 275. 
mientras apoyaban a sus copartidarios en $\operatorname{armas}^{43}$. En Albania, por ejemplo, fue preferible efectuar las capturas de los rebeldes con miembros de la policía nacional, en la medida en que la departamental recibía «la acogida francamente hostil de los habitantes de la región, que les merma recursos y desarrolla una labor tan activa como la otra en perjuicio de sus actividades y en beneficio de sus perseguidos» ${ }^{44}$. Hay que resaltar que hubo casos en que miembros de la fuerza pública llegaron a rebelarse en contra de los alcaldes, y a enfrentar a sus compañeros y copartidarios para frenar este tipo de atropellos. Así ocurrió en San Andrés, durante un tiroteo en la plaza, cuando dos soldados impidieron que el sacerdote, doctor Colmenares, fuera fusilado por orden del alcalde ${ }^{45}$. Incluso, el propio comité liberal de dicho pueblo se quejó ante el Ministro de Gobierno por las actuaciones de la policía, «triplemente censurables por cuanto que en su mayor parte son efectuadas en momentos de completa borrachera», motivo por el cual Morales Olaya solicitó las correspondientes investigaciones y el retiro de los cargos para los agentes implicados ${ }^{46}$.

El obispo de Pamplona, Rafael Afanador y Cadena, en carta enviada al presidente, informó sobre la actuación de la policía en estas regiones. Según

43 Guerrero, 2007: 11 y 112.

44 Informe al Gobernador de Santander, AGN, AA2, MG, S4ta, Justicia, Orden Público-Informes, caja 1, carpeta 3, fols. 95, 96 y 97. El dirigente conservador Laureano Gómez, sostuvo que la impunidad con la que actuaba la policía contra los campesinos conservadores se debió a que muchos alcaldes pertenecían a este cuerpo armado, sin ni siquiera depender de las gobernaciones, sino de la Dirección General de la Policía. Gómez, 1934: 78.

45 Navia a Gómez, 18 de septiembre de 1932, AGN, AA2, MG, S4ta, Justicia, Orden Público-Informes, caja 1, carpeta 4, fols. 148-150. Guzmán, 1968: 29-32. Muchos católicos creyeron ser víctimas de una persecución anticlerical sistemática, sentimiento que se afianzó tras el asesinato de los párrocos Orduz y Reyes, de Molagavita y Bochalema, respectivamente, quienes fueron vistos como verdaderos mártires. Vázquez, 2012: 203-204 y 224-233. En todo caso, fueron frecuentes los casos de ataques al clero, por parte de liberales, cuando se le acusaba de apoyar a los conservadores; y, por estos últimos, si los sacerdotes no se mostraban suficientemente comprometidos con las banderas de este partido. El País, Bogotá, 27 de julio de 1933: 1. El Tiempo, Bogotá, 2 de noviembre de 1933: 6; 15 de enero de 1931: 15; 13 de julio de 1932: 12; 22 de agosto de 1932: 6. Este último artículo menciona, además, las actuaciones de un grupo de guardas de rentas conservadores de Villa Caro, que lanzaron «abajos» contra el presbítero de Mocoa, «ejemplar sacerdote, quien no participa en escándalos».

46 Morales al Comandante Policía en San Andrés, 7 de marzo de 1933, AGN, AA2, MG, S4ta, Justicia, Correspondencia-Telegramas, caja 4, carpeta 4, fol. 186. Por otra parte, el comandante de la policía nacional, Gustavo Gómez, llamó la atención a su subalterno Pablo Aza porque los hombres bajo su mando usaban un pañuelo rojo (color insigne del partido liberal) como distintivo en el cuello, aunque, según éste, «lo del pañuelo rojo» era una «torpe y ridícula calumnia». Aza a Gómez, 14 de junio de 1932, AGN, AA2, MG, S4ta, Justicia, Correspondencia-Telegramas, caja 5 , carpeta 1 , fol. 82 . 
el prelado, a pesar de las medidas tomadas (las cuales no son especificadas en el documento), los abusos continuaban y el enviado del gobierno, el capitán Gómez Posada, no mostraba verdadero interés ni en escuchar las quejas presentadas personalmente por el Obispo, ni en promover los cambios esperados; mientras tanto, los campesinos reclamaban que la policía fuera removida de sus veredas. Asimismo, Afanador describió la forma en que las familias salían huyendo de sus pueblos para refugiarse en los montes; o, de lo contrario, no les quedaba más remedio que someterse e «ir amarrados a la cárcel». Todos estos campesinos vivían bajo la permanente amenaza de que sus casas fueran incendiadas y de morir bajo los disparos de sus agresores. Y añadía, respecto a la impunidad de los asesinatos ocurridos en Salazar, a plena luz del día, que aunque no habían sido cometidos directamente por la policía, «los ejecutores no se hubieran atrevido a tanto si no hubieran contado con ese respaldo. ¡Entiendo que hasta ahora no se ha hecho la menor sanción!». A los homicidios, detenciones, desplazamientos forzosos, impunidad y a la indigencia en la que quedaban estas gentes, había que añadir las calumnias que alcanzaron, incluso, a la persona del Obispo, a quien la policía acusó de guardar un parque de armas que había hecho pasar a Venezuela, motivo por el cual, el prelado invitaba al presidente a requerir las pruebas de «tan maliciosa invención, pues ni yo tengo parque ni he sido hombre de armas.... $\rangle^{47}$.

El ejército, por su parte, en general mostró una posición más ecuánime, profesional y menos sectaria ${ }^{48}$. La investigadora Olga Yaneth Acuña, encuentra claras diferencias entre la actuación de esta institución y la policía y, en este sentido, se afianza en la tesis previamente expuesta por historiadores como Patricia Pinzón Lewin ${ }^{49}$. Parece ser entonces, que dicha fuerza desempeñó su papel con mayor imparcialidad, mientras que la policía estuvo más claramente politizada, puesto que la designación de sus integrantes y las funciones que le eran encomendadas obedecían a los requerimientos e instrucciones directas de los jefes y caciques locales y regionales. Es necesario aclarar que no obstante los ingentes esfuerzos de profesionalización por parte del gobierno durante la hegemonía conservadora (1886-1930), el ejército no fue inmune al sectarismo y a las consecuentes preferencias políticas conser-

47 Afanador a Olaya, 23 de julio de 1932, Archivo Arquidiócesis de Pamplona (AAP), Copiadores, caja 10, libro 1, Comunicaciones, fols. 965 y 966.

48 Porras a Olaya, 15 de septiembre de 1932, AGN, AA2, MG, S4ta, Justicia, Correspondencia-Telegramas, caja 3, carpeta 3, fol. 132. El Nuevo Tiempo, Bogotá, 1 de julio de 1931: 1.

49 Pinzón, 1994. 
vadoras de la oficialidad; sin embargo, como afirma Adolfo Atehortúa, «los cuerpos directamente encargados de velar por la tranquilidad electoral, guardias o policías», fueron precisamente «los más resueltos a la intervención, debido a su dependencia con respecto a las autoridades locales» ${ }^{50}$.

El informe acerca de la situación de orden público en Albania, presentado por el capitán Camilo Callejas, narra la actuación conjunta de policías y civiles armados en contra de los conservadores, y la posición asumida por el ejército para impedir dichos ataques. Callejas, se encontró con que unos mil hombres de filiación liberal se disponían a atacar el pueblo «perfectamente organizados, fusil grass, cornetas, apoyados por policía departamental Santander, banderas rojas» ${ }^{51}$. Cuando la policía ingresó al pueblo, con el pretexto de un compañero desaparecido intentó presionar al ejército para que le ayudara a acabar con las gentes del lugar. Callejas se negó y acto seguido ordenó a la policía departamental que se retirara; ésta, al evacuar sembró el pánico, incendió viviendas y asesinó campesinos conservadores. El oficial denunció la grave situación de orden público y la forma en que poblaciones como Encenillo, Cacho Venado, Tununguá, Soure, Jesús María, Bolívar, El Hatillo y otras, se preparaban para el combate, e invitó al Ministro de Gobierno a «meditar seriamente sobre el grave problema que se avecina, si este movimiento no es debelado enérgicamente y con la imparcialidad honrada que el país reclama» ${ }^{52}$. Desafortunadamente, esa imparcialidad no se hizo efectiva entonces, ni tampoco después, cuando los conservadores retomaron el poder en 1946 y la violencia bipartidista se agudizó y cubrió, prácticamente, todo el territorio nacional.

Pero volvamos al capitán Callejas, quien también tuvo que vérselas, otra vez en Albania, con una cuadrilla de liberales de unos doscientos integrantes, quienes en nombre del gobierno y de los resguardos armados reclamaban por la sangre de sus compañeros. Entonces, se dispusieron a disparar sobre los habitantes que estaban dispersos en la plaza. El oficial no tuvo otro camino que intervenir, por segunda vez, situándose con dos soldados, en medio del inminente enfrentamiento. Afortunadamente, su orden de cese al fuego fue suficiente para detener el tiroteo. Ante este tipo de situaciones, el oficial sugirió las soluciones más adecuadas para la pacificación de esta región: el nombramiento de autoridades de filiación conservadora, pues «la Concentración en estos pueblos no conviene porque el fanatismo y barbarie no lo per-

50 Atehortúa, 2009: 185 y 205-210. Acuña, 2006: 2.

51 Callejas al Ministro de Guerra, 25 de octubre de 1932, AGN, AA2, MG, S4ta, Justicia, Correspondencia-Telegramas, caja 5, carpeta 1, fols. 178 y 179.

52 Idem. 
mite»; y que se detuviera el envío de más policías a dicho lugar. Asimismo, advirtió sobre el papel del alcalde Marco Díaz, quien dirigía a la gente que iba a atacar el pueblo y el cual, «viendo mi actuación, abandonó la población en compañía de policía departamental, resguardos, gente armada» ${ }^{53}$.

Así, los ataques cometidos por la policía, dirigida a su vez por los alcaldes y gamonales, tuvieron como resultado, por lo menos en casos como el anterior, un enfrentamiento con los oficiales del ejército. Cuando el comandante de la guarnición de Guaca, teniente Julio Garzón, recibió una orden de traslado, redactó un informe al Ministro de Guerra con el fin de aclarar sus actuaciones, contrarias al alcalde de esa población, dedicado a cometer todo tipo de abusos con la complicidad de la policía, obstaculizando con tan pésimo ejemplo, la acción pacificadora del ejército ${ }^{54}$; pues, efectivamente, la indignación había llevado a los campesinos conservadores a atacarlo, al confundirlo con la policía. Ante esta situación, no es de extrañar que el oficial considerara probable que el hecho de no convenir con los procedimientos de las autoridades inescrupulosas era el motivo real de las falsas informaciones en su contra, formuladas con el ánimo de producir su traslado. Finalmente, comparaba la adecuada formación y el comportamiento de los miembros del ejército con los de la policía. En todo caso, lo cierto fue que al menos en esta ocasión, y gracias al anterior informe, el alcalde Andrés Márquez recibió orden de presentar su renuncia y el gobierno dispuso el inicio inmediato de una investigación en su contra $^{55}$.

Por otra parte -tal como había sucedido en épocas anteriores y continuaría ocurriendo después-, el permanente ambiente electoral y las prácticas corruptas que lo acompañaban ${ }^{56}$, se convirtieron en factores detonantes de los episodios violentos en los pueblos. Las autoridades de uno y otro partido efectuaban continuas revisiones de las listas de votantes, con el resultado de que, el día de las elecciones, habían desaparecido nombres de los sufragantes. Por lo tanto, antes de los comicios, los campesinos de los dos bandos marchaban a los pueblos a registrarse nuevamente. Una vez llegaban a la plaza principal en busca de las oficinas del jurado electoral, se presentaban los altercados con sus oponentes, apoyados estos últimos por las autoridades de la localidad ${ }^{57}$.

53 Idem.

54 Ministerio de Guerra al de Gobierno, 14 de enero de 1933, ibidem, Orden Público-Informes, caja 1, carpeta 3, fols. 113-116.

55 Gómez a Morales, 17 de enero de 1933, ibidem, fol. 117.

56 El Tiempo, Bogotá, 27 de marzo de 1929: 1. Sobre este mismo fenómeno, en la hegemonía conservadora (1946-57), Acuña, 2008: 5, 6, 13 y 14.

57 Henderson, 2006: 266 y 267. El Nuevo Tiempo, Bogotá, 29 de octubre de 1930: 1. 
Un ejemplo que ilustra este tipo de situaciones, se puede encontrar en el informe enviado por el juez de la policía nacional de Chinácota, Mateo Franco, al ministro Morales Olaya, sobre las elecciones celebradas el 5 de febrero de 1933. En tal ocasión, los bandos terminaron enfrentados a palo y tiros de revólver, lo que conllevó a la intervención de agentes de la policía nacional y municipal y varios guardas de rentas, unos veinticinco individuos, aproximadamente, quienes terminaron por disparar indiscriminadamente a la población, mientras a su vez, recibían descargas por parte de algunos particulares ubicados en varios puntos de la plaza. El ejército, por su lado, mostró nuevamente una actitud más imparcial durante y después de estos sucesos. Cuando aparecieron los soldados en la esquina noroeste, bajo el mando del teniente Laurentino Fernández "cesaron los fuegos como por ensalmo», de tal suerte que no tuvieron necesidad de emitir un solo disparo. La policía, entonces, se vio obligada a explicar su proceder, pero su versión de los hechos fue desmentida por los militares y por el testimonio de muchos de los presentes.

El juez Franco hizo un análisis sobre la posible causa del incidente: la ostentación de fuerza que quisieron hacer liberales y conservadores con motivo de las elecciones de ese día. Como la lucha en las urnas se mostraba reñida y el triunfo era dudoso para los dos bandos, se propagó entre los votantes un clima de nerviosismo que llevó a los campesinos al enfrentamiento a golpes, situación que finalmente se vio agravada por la «falta de serenidad de los agentes de la policía nacional, departamental y municipal, quienes dispararon sobre la multitud sin consideraciones de ninguna especie». Asimismo, Franco creyó prudente dejar pasar unos días antes de efectuar las detenciones correspondientes, ya que arrestar a los civiles involucrados, sin hacer lo mismo con los policías, habría dado pie a comentarios sobre la parcialidad de la justicia, y dirían, no sin razón «que aparte de que el pueblo es abaleado por las fuerzas oficiales se le reduce a prisión». Por lo demás, al dictarse órdenes de captura sobre los agentes, la autoridad de la policía habría quedado totalmente en entredicho. Con el fin de evitar sucesos similares, recomendó que los integrantes de la policía nacional del departamento fueran reemplazados por otros de distintas regiones del país. Esto, debido a que muchos de ellos eran naturales de esas tierras, y habían sido despojados violentamente de sus propiedades, por lo cual apelaban al empleo público para atender a las necesidades de su subsistencia; y, por lo demás, estaban directamente involucrados en los rencores y odios, lo que daba margen para que se murmurara sobre la parcialidad de sus actuaciones, «rumor que no deja de tener su base razonable». Por otra parte, el Juez hizo una descripción general del clima de violencia que se vivía en la región, de los odios partidistas y de las soluciones más adecuadas para la pacificación, prefiriendo las medidas educativas 
sobre la fuerza, para inculcar el valor de la vida, desconocido en esas tierras, donde incluso, mujeres y niños «han sido víctimas de represalias de estas hordas salvajes, sin haber siquiera visto la luz del sol, en las entrañas maternas». Finalmente, explicó la causa de fondo que había desatado la reciente explosión de odios heredados: la corrupción y los abusos de las autoridades locales, muchas veces a espaldas de sus superiores, y la manipulación de los sentimientos revanchistas por parte de los políticos ${ }^{58}$.

Nuevamente encontramos, entonces, que los principales artífices de la Primera Violencia, en el escenario de los hechos, fueron las autoridades civiles y de policía a nivel local, directamente relacionadas, como ya se ha mencionado, con los caciques y los respectivos directorios departamentales de cada partido, vinculados éstos, a su vez, a los jefes políticos nacionales. En este sentido, cabe destacar el papel de quienes incitaron y perpetraron los ataques, como también de los que empujados por el mismo tipo de intereses electorales, promovieron de forma oportunista las revanchas. En consecuencia, un análisis de la violencia bipartidista de este período debe tener en cuenta la manera en que gamonales de uno y otro partido, ejercieron su influencia para incitar a la violencia y a la venganza, obteniendo con ello los respectivos dividendos políticos en las urnas.

Por otro lado, la responsabilidad de la fuerza pública en la violencia llevó a una situación crítica, a tal punto que el ministro de gobierno, Morales Olaya, manifestó al Procurador General de la nación, en tono un tanto irónico, su preocupación porque los jueces, especialmente los municipales, venían levantando sumarios a los agentes de policía o del ejército, proceder que a la larga terminaría por reducir a prisión a «todo el cuerpo de policía, inclusive a su director» ${ }^{59}$.

\section{LOS BANDOLEROS}

Es importante destacar que durante la década del treinta, también los «bandoleros políticos» actuaron bajo la complicidad y el apoyo de los caciques o gamonales ${ }^{60}$. Así, el gobernador de Santander, Cadena D’acosta, se

58 Franco a Morales, 23 de febrero de 1933, AGN, AA2, MG, S4ta, Justicia, Orden Público-Informes, caja 1, carpeta 3, fols. 208-213.

59 Morales al Procurador, 26 de agosto de 1932, ibidem, Correspondencia-Telegramas, caja 4, carpeta 2, fol. 123.

60 En este contexto eran frecuentes ejemplos como el del alcalde conservador de El Espino -hermano del célebre cabecilla Próspero Abril- quien recorría los campos con más de cincuenta hombres persiguiendo a los liberales. El Tiempo, Bogotá, 1 de junio de 1933: 6. 
quejó de que en la región de García Rovira existiera el «tipo clásico de agitador político, que sabe encender las pasiones y mantiene a su disposición en casa o hacienda varios criminales empecinados para usarlos como instrumentos de sus campañas» ${ }^{61}$.

En todo caso, en este punto es importante precisar que, en ausencia de estudios que presenten una categorización apropiada sobre la actividad bandolera y para-institucional durante la violencia de los años treinta, fue necesario remitirse al planteamiento de los investigadores Meertens y Sánchez, sobre el bandolerismo en Colombia a finales de los cincuenta y durante los inicios del Frente Nacional, para retomar aquellos elementos aplicables a la Primera Violencia. Los autores diferencian entre el bandolerismo político y el social, y consideran que el primero se ajusta al caso colombiano por sus fines y las solidaridades establecidas con las redes del poder local y regional entretejidas a través de las diferentes instancias del modelo bipartidista. Dicho estudio caracteriza el bandolerismo político por «el apoyo militante o pasivo de las comunidades rurales de su misma identidad partidaria», y por la «protección y orientación de gamonales que, utilizándolos [a los bandoleros] para fines electorales, los empujaban a una guerra de exterminio, debilitamiento o contención de sus adversarios en la estructura del poder local o regional». Por otra parte, vale la pena tener en cuenta que, tal como lo señalan dichos autores, aunque el número de integrantes constituya un elemento esencial para la diferenciación de los distintos actores sociales en el escenario de la violencia bipartidista, las conexiones institucionales o semi-institucionales del bandolerismo político, le permite expresarse en términos más masivos que el bandolerismo social. Lo anterior también permitiría entender por qué los bandoleros de los años treinta, en principio reunidos en un relativamente reducido número, eventualmente podían sumarse, ya bien a las autodefensas conservadoras o a la policía y guardias de rentas, bajo el liderazgo de los alcaldes y gamonales, en momentos coyunturales del conflicto ${ }^{62}$.

Como ya se mencionó, dichos bandoleros contaron, desde un comienzo, con el respaldo de las comunidades campesinas copartidarias, que seguramente vieron en ellos a unos defensores y protectores, incluso más eficaces que el propio Estado. Por supuesto, el afecto y el apoyo de la población dificultaban su captura ${ }^{63}$. Estos bandoleros se dedicaron a atacar a los enemigos de

61 Ibidem, 10 de diciembre de 1931: 1 y 9.

62 Sánchez y Meertens, 2000: 42, 47 y 92.

63 Informe al Gobernador de Santander, 22, 23 y 24 de octubre de 1932, AGN, AA2, MG, S4ta, Justicia, Orden Público-Informes, caja 1, carpeta 3, fols. 95, 96 y 97. Ver también, Buitrago y Ojeda a Mendoza, 12 de julio de 1932, AGN, AA2, MG, S4ta, Justicia, Orden 
su partido a través del terror, las venganzas, los atentados personales y la presión para eliminar físicamente a sus contrarios u obligar a los desplazamientos que garantizaran el triunfo electoral y el despojo de tierras. Dependiendo de la estructura del poder regional, los bandoleros liberales y conservadores desempeñaban, alternativamente, las funciones de resistencia respecto a las autoridades civiles pertenecientes al partido contrario, o de fuerzas sectarias parainstitucionales ${ }^{64}$. De esta forma, los bandoleros conservadores fueron, durante la Primera Violencia, una de las prioridades en los operativos de la fuerza pública, que debió enfrentar, además, el mencionado respaldo de la población y de los alcaldes y gamonales de dicho partido. Tal soporte, impedimento para la detención de estos individuos, constituye una de las características esenciales del bandolerismo político propio de la violencia bipartidista, de los años treinta:

La captura de tales sujetos se hace sumamente difícil debido al mismo miedo que las gentes les tienen y además, porque debido a asuntos políticos les alcahuetean y les hacen el alto. El sábado en las horas de la mañana tuve conocimiento de que en la parte alta de la población y en una venta de guarapo, estaba el famoso Evelio Ruiz, requisitoriado por muchas autoridades, en compañía de dos de los Garcías. De acuerdo con el capitán Gómez Pereyra organizamos lo conveniente para obtener su captura, pero tal cosa no nos fue posible pues los mismos habitantes del pueblo se apresuraron a darles el aviso, tan pronto se dieron cuenta de que la autoridad tenía conocimiento de su presencia en la ciudad. [...] A mi manera de ver las cosas, y como opinión puramente personal, creo que se hace indispensable el cambio, por personal de la Policía Nacional, de los alcaldes de Boavita, La Uvita y Susacón, pues los alcaldes existentes son compinches y alcahuetes de los malhechores y hasta se ha visto el caso del Alcalde de Susacón de estar tomando licor con el famoso Juan Hernández; el alcalde de Boavita le presta su caballo y le suministra dinero al mismo bandolero y lo mismo hace el de la Uvita. Son por lo tanto autoridades que ninguna garantía dan y que al mismo tiempo hacen nugatoria la acción nuestra en ésta región. Con tal clase de autoridades, no será nunca posible obtener la captura de la cuadrilla de bandidos ${ }^{65}$.

Público-Informes, caja 1, carpeta 4, fols. 107 y 108; y Ministro de Gobierno al de Guerra, 14 de julio de 1932, fol. 131.

64 Precisamente, con el fin de proponer un enfoque que lograra integrar la relación dinámica represión-resistencia, Sánchez y Meertens diferenciaron entre los «bandidos del poder» y los «bandidos del pueblo». Sánchez y Meertens, 2000: 14.

65 Navia a Gómez, 30 de agosto de 1932, AGN, AA2, MG, S4ta, Justicia, Orden Público-Informes, caja 1, carpeta 3, fols. 129 y 130; y Secretaría del Senado a Morales, 2 de septiembre de 1932, ibidem, fol. 145. Tanto Ruíz como Hernández, fueron capturados en 1933. Guerrero afirma que, al menos el segundo, cayó en manos de sus copartidarios, lo que permite preguntarse hasta qué punto dichos sujetos habían perdido el respaldo de sus comunidades, lo que explicaría su detención por parte del gobierno. Ya para 1934, la campaña de pa- 
Por otra parte, del lado liberal también se hizo famoso el apoyo y la complicidad de las autoridades con los bandoleros de su partido, tal como lo describió el padre Landazábal, párroco de San Andrés, al Ministro de Gobierno. Según su informe, estos bandidos eran conocidos por el alcalde y, sin embargo, no había ningún interés en perseguirlos. Pero cuando un conservador iba a quejarse de ultrajes padecidos a causa de ellos no era recibido, con el argumento de que «cómo iban los liberales a tirarse unos a otros». Asimismo, puso en conocimiento del gobierno la relación entre el alcalde y uno de los más conocidos bandoleros de la región, Ernesto Martínez, «salteador, incendiario, jefe de cuadrilla»; e informó cómo lo habían exhortado a que frenara sus actividades, ofreciéndole no ser molestado por sus delitos anteriores. Además, el padre Landazábal relató lo que escuchó de los labios de un policía, después de un homicidio: según este, siguió al asesino por algún trecho y ordenó el envío de una comisión, pero justamente del lado opuesto para evitar su captura, mientras que por el camino de vuelta iba «estropeando a la gente pacífica, y llevándolos a la cárcel a culata». De esta manera, concluía el párroco, «mientras no haya un alcalde imparcial, no podrá haber verdadera paz. Mientras no persigan a los verdaderos malhechores, no habrá denuncios ni declaraciones, porque quien se atreva a esto, firma su sentencia de muerte» ${ }^{6}$.

Es importante subrayar el hecho de que la detención de los bandidos se complicaba aún más, dado que la policía se tropezaba con «las aspiraciones de los políticos de Bogotá, de las provincias y de los municipios», para quienes aquellos individuos no eran considerados malhechores, «siempre que tengan la condición de ser adictos servidores a determinada causa política ${ }^{67}$. De tal forma que si eran tomados prisioneros aquellos «sujetos homicidas, ladrones de ganado mayor o incendiarios», pronto sus copartidarios solicitaban que fueran liberados, con el argumento de que sus capturas obedecían al sectarismo, a las pasiones políticas y al abuso de autoridad ${ }^{68}$. De esta manera, evidenciamos una vez más la forma cómo a través de este tipo de mecanismos,

cificación dejaría un saldo de 150 bandoleros capturados. Guerrero, 2007: 156. El Espectador, Bogotá, 26 de julio de 1935: 1 y 3.

66 Landazábal a Morales, 16 y 27 de febrero de 1933, AGN, AA2, MG, S4ta, Justicia, Orden Público-Informes, caja 1, carpeta 3, fols. 194-197.

${ }^{67}$ El Tiempo, Bogotá, 26 de julio de 1935: 1 y 3. De hecho, la legitimidad del bandolero y la calificación que recibía dependía de las relaciones con los jefes y gamonales de su colectividad política. Sánchez y Meertens, 2000: 48 y 92.

68 Acerca de las dificultades de la policía para la captura de los bandoleros conservadores de la población boyacense de Saboyá, ver: Gómez a Morales, 10 de diciembre de 1932, AGN, AA2, MG, S4ta, Justicia, Orden Público-Informes, caja 1, carpeta 4, fol. 180. 
la impunidad quedaba a la orden del día, gracias a la actitud solidaria de los dirigentes de los partidos con quienes en nombre de su colectividad actuaban al margen de la ley, puesto que, «todo sindicado por todo asesinato puede estar seguro de que sus copartidarios lo apoyan con dinero, con influencias y aún con elementos para fugarse, circunstancias que influyen poderosamente en la no instrucción de los sumarios» ${ }^{69}$.

De esta forma, si bien en su momento Javier Guerrero intuyó la posible afinidad entre el bandolerismo político propuesto por Sánchez y Meertens, con los bandoleros de los años treinta ${ }^{70}$, la presente investigación propone la aplicabilidad de dicha categoría y considera la existencia de este fenómeno en situaciones político-culturales afines, por lo menos en las sociedades de herencia hispánica, como era el caso colombiano de los años treinta; $\mathrm{y}$, por consiguiente, lo concibe a su vez como parte inherente y constitutiva del bipartidismo, no sólo durante la Violencia y sus rezagos en los primeros años del Frente Nacional, sino también, posiblemente, en etapas anteriores. En todo caso, este aspecto podría abrir nuevas puertas para la indagación y la interpretación histórica, sobre este tema, en particular.

\section{Las autodefensas: ¡Avance la CUadrilla de PaCho Jaimes!}

Es un hecho que el estado semipermanente de guerra contribuyó a despertar un ambiente de nerviosismo entre los moradores rurales de la región nororiental del país, y a que buscaran agruparse de forma organizada para su propia defensa ${ }^{71}$. Como sucedió en posteriores etapas de la violencia, los grupos de autodefensas - esta vez conservadoras- adoptaron los nombres de los jefes de su partido ${ }^{72}$, y fueron calificados de bandoleros por el gobierno liberal de turno. Por otro lado, la simpatía y el eventual apoyo recibido, por parte de algunos miembros del clero, obedeció, en general, a la idea de que los campesinos tenían derecho a una legítima defensa. Así lo refiere el siguiente telegrama del presbítero Luis Pinzón -quien había reemplazado al

69 Memorándum sobre situación de los dos Santanderes, ibidem, carpeta 3, fol. 81.

70 Observaba Guerrero en su momento que la comprobación de la hipótesis que ahora verificamos, representaría un hecho de «gran significación en cuanto a la formas de confrontación bipartidista», acorde con la tipificación de lo que «ha caracterizado Gonzalo Sánchez, retomando la tipología de bandidos de Eric J. Hobsbawn, como bandidismo político». Guerrero, 2007: 240, nota 213.

71 Memorándum sobre situación de los dos Santanderes, AGN, AA2, MG, S4ta, Justicia, Orden Público-Informes, caja 1, carpeta 3, fol. 81.

72 Guerrero, 2007: 139 y 140. 
asesinado padre Orduz de Molagavita, muerto a manos de la policía-, en el que denunciaba la connivencia entre la fuerza pública y los bandoleros liberales, la impunidad y el recurso válido de defensas por parte de las víctimas: «... sobrevivientes causa, apréstanse defensa heroica, único recurso quédales para reemplazar garantías, derechos gobierno empéñase en negarles» $\rangle^{73}$. A su vez, el Obispo de Pamplona, aunque no las justificara, explicaba los motivos de las autodefensas conservadoras; si bien, reconocía los muertos del lado liberal, sostenía que «esto no vino sino cuando las gentes, desatendidas en sus repetidos reclamos», y luego de haber visto abalear a sus sacerdotes, «resolvieron repeler la fuerza con la fuerza» ${ }^{74}$. En este orden de ideas, cabe recordar que de acuerdo con los testimonios de los protagonistas de este conflicto, recogidos por el historiador Helwar Figueroa, bandoleros conservadores, como por ejemplo, Alcides García, realizaban sus correrías con el abierto apoyo del clero boyacense ${ }^{75}$.

No resulta sorprendente, entonces, que la composición numérica de las autodefensas conservadoras fuera considerable, como lo demuestran las conversaciones telefónicas de los rebeldes interceptadas por el gobierno, cuando se disponían a reunir en algunos municipios de Boyacá a cuatrocientos hombres que pedían refuerzos mutuamente, en un «verdadero movimiento revolucionario», bajo el mando de los alcaldes y párrocos de Boavita y La Uvita ${ }^{76}$. Asimismo, en la región de Santa Bárbara, Norte de Santander, ocho comisiones, probablemente de la policía (el documento no lo aclara), fueron atacadas por más de doscientos hombres, armados con grasses y revólveres que, al grito de «avance la cuadrilla de Pacho Jaimes» ${ }^{77}$, persiguieron a los uniformados y los obligaron a huir por cinco leguas dentro de la montaña ${ }^{78}$.

73 Pinzón y otros a Olaya y Morales, 1 de abril de 1932, AGN, AA2, MG, S4ta, Justicia, Correspondencia-Telegramas, caja 5, carpeta 1, fol. 44. Ejemplos similares en: Javier Guerrero, 1991: 127-129.

74 Informe de Afanador, 4 de junio de 1932, AAP, Copiadores, caja 10, libro 1, Comunicaciones, fols. 946 y 947.

75 Figueroa, 2007: 365, 368 y 370-372.

76 Ministro de Gobierno al de Guerra, 7 de julio de 1932, AGN, AA2, MG, S4ta, Justicia, Orden Público-Informes, caja 1, carpeta 3, fol. 34. Como los telegramas de orden público eran ocasionalmente alterados, los funcionarios enviaron al ministro Morales una copia autenticada del mismo. Alcaldía de Capitanejo (firma ilegible) al Ministerio de Gobierno, 9 de julio de 1932, ibidem, Correspondencia-Telegramas, caja 4, carpeta 2, fols. 102 y 103; y Pinzón a Morales, 6 de julio de 1932, fols. 95 y 96.

77 Pacho Jaimes, presunto jefe de las autodefensas conservadoras, sobre el que no tenemos, por lo pronto, mayores referencias.

78 Gobernador de Norte de Santander al Ministro de Gobierno, 22 de enero de 1933, AGN, AA2, MG, S4ta, Justicia, Orden Público-Informes, caja 3, carpeta 3, fol. 178. 
Dichas autodefensas efectuaban acciones ofensivas, reunían cientos de hombres bajo el amparo de políticos (léase gamonales) conservadores; tenían una organización militar propia y contaban con armamento de largo alcance ${ }^{79}$, un servicio de seguridad permanente y campos de tiro para los entrenamientos $^{80}$. Como en Norte de Santander era usual el contrabando con Venezuela, las autodefensas conservadoras acudieron a este recurso, añadiendo con ello un motivo más para los enfrentamientos con la policía, que no daba abasto para asumir por sí sola el caos y la vigilancia de las fronteras. Así, cuando el comisionado Chavarriaga se dirigía a Ragonvalia, primero se presentó en el alto de Babilonia, en donde encontró alrededor de unos doscientos cincuenta hombres cuyo objetivo era impedir su entrada al pueblo. Como de todas maneras lograra ingresar a dicha población, en la plaza tuvo que sortear la presencia de otros ochocientos a mil individuos que protestaban contra el gobierno de forma amenazante. El oficial y sus hombres permanecieron sitiados por un lapso de diecinueve horas, a sabiendas de que en las afueras, cerca de la frontera con Venezuela, se encontraban más rebeldes. Luego de advertir que en Babilonia las gentes estaban en abierta «pugna con las instituciones», avisó que las líneas telefónicas y telegráficas habían sido rotas, razón por la cual estaba completamente incomunicado. Estos rebeldes, «todos contrabandistas reconocidos», y organizados en "cuadrillas de malhechores», debían ser enfrentados, según su parecer, con hombres del ejército que respaldaran a la policía, de tal forma que los bandoleros, «casi constituidos en gobierno independiente», dejaran de defraudar el erario público y de perjudicar el comercio lícito que sí pagaba derechos de importación ${ }^{81}$. De esta forma, como en períodos posteriores de la historia nacional, grupos armados al margen de la ley ejercían actividades económicas ilícitas, para su sostenimiento, como era en este caso el contrabando, y vivían bajo una organización parainstitucional propia.

Por lo demás, ya hemos mencionado cómo los directorios departamentales promovieron inicialmente las hostilidades sectarias; pero una vez se dieron cuenta de la gravedad de la situación, las muertes de sus copartidarios por las retaliaciones y venganzas, del estancamiento económico y la manera como sus intereses personales se veían afectados, era ya demasiado tarde, y sus llamados a la paz fueron desatendidos por los mismos que en un principio

79 Ministro de Gobierno al Ministro de Guerra, 14 de julio de 1932, ibidem, caja 1, carpeta 4 , fol. 131.

80 Morales a Perdomo, 17 de diciembre de 1932, ibidem, carpeta 3, fol. 1.

81 Dirección General de la Policía Nacional al Ministro de Gobierno, 13 de junio de 1932, ibidem, Correspondencia-Telegramas, caja 5, carpeta 2, fols. 27 y 28. 
actuaron bajo sus órdenes ${ }^{82}$. Para 1932, Olaya intervino con el fin de impedir la formación de milicias liberales por parte del líder Jorge Eliécer Gaitán, y ordenó que se disolvieran los «ejércitos partidistas» en todo el territorio nacional, refiriéndose por igual a la guardia civil liberal y a las milicias conservadoras y liberales ${ }^{83}$.

En este sentido, vale la pena destacar que ni siquiera un acontecimiento trascendental como lo fue la guerra con el Perú, puso freno a la violencia bipartidista, en las regiones estudiadas. Efectivamente, el primero de septiembre de 1932, el país quedó conmocionado con la noticia de que los peruanos habían tomado militarmente el puerto de Leticia, hecho que dio inicio a la guerra Colombo-Peruana, que se prolongó hasta $1933^{84}$. El asunto fronterizo despertó el sentimiento nacionalista expresado en emotivos discursos y multitudinarias manifestaciones. Los odios partidistas entre los jefes de las dos colectividades quedaron en un segundo plano y la jerarquía eclesiástica mostró su solidaridad con el gobierno en la defensa de los derechos sobre las fronteras colombianas en el Amazonas. De esta manera, en todo el país concurrieron las autoridades civiles, militares y religiosas para conformar los comités patrióticos encargados de avivar el sentimiento nacionalista y recoger los fondos para la defensa ${ }^{85}$. Hay que reconocer que la guerra tuvo múltiples y variadas consecuencias, entre ellas el ya mencionado sentimiento de unidad entre los partidos, aunque este no siempre repercutiera en el cese de hostilidades en las regiones rurales del nororiente colombiano. Allí, por ejemplo, el padre Luís Alberto Castillo solicitó ser removido como capellán a Leticia, pues sostenía sentirse «cobarde para morir asesinado por los colombianos», razón por la cual, prefería quedar a merced de las fieras o de los peruanos ${ }^{86}$, puesto que efectivamente, en dichos departamentos, a pesar de la guerra con el Perú, como bien sabemos, la violencia continuó su fatídico curso.

82 Memorándum sobre la situación de los dos Santanderes, ibidem, Orden Público-Informes, caja 1, carpeta 3 , fols. 83 y 84 .

83 Henderson, 2006: 273. Horgan, 1983: 542.

84 Restrepo y Betancur, 2001. Horgan, 1983: 480-539.

85 Rueda a Morales, 8 de octubre de 1932, AGN, AA2, MG, S4ta, Justicia, Correspondencia-Telegramas, caja 4, carpeta 2, fol. 205. El Tiempo, Bogotá, 19 de septiembre de 1932: 1 y 12. El Porvenir, Bucaramanga, 8 de octubre de 1932: 1 y última.

86 Castillo a Afanador, 27 de febrero de 1933, AAP, Rafael Afanador y Cadena, caja 4, libro 1, carpeta 2, Correspondencia con parroquias, s./fol. 


\section{CONCLUSiones}

Evidentemente, hasta el momento el aporte más importante sobre este ciclo de violencia, por lo menos en Boyacá, ha sido la obra ya citada del historiador Javier Guerrero; así mismo, los estudios de Olga Yaneth Acuña sobre la actuación de la policía en el escenario de la violencia bipartidista han permitido profundizar en la dinámica política de este período, también en dicho departamento. No obstante, el presente artículo amplía la consulta y el análisis de fuentes, e incluye también otras ubicaciones geográficas del nororiente colombiano, correspondientes a los departamentos de Santander del Norte y Santander del Sur, limítrofes con Boyacá; adicionalmente, la documentación consultada en archivos religiosos, como el Archivo Secreto Vaticano y el de la Diócesis de Pamplona, ofrece una percepción particular sobre estos hechos, hasta el momento escasamente tenidas en cuenta, pues en general, las referencias efectuadas han sido producto de la revisión de la prensa de la época, que tenía entre sus principales objetivos, servir como instrumento de la lucha y la propaganda sectaria.

En todo caso, podemos concluir, que la Primera Violencia fue resultado, en buena medida, del ejercicio sectario del poder por parte de las autoridades regionales y municipales, aspecto que ya ha sido reconocido por los estudios clásicos del tema, como los citados en el presente artículo. Sin embargo, subrayamos el hecho de que esta responsabilidad recayó en dichos actores, al menos en igual o mayor medida que en algunos de los principales dirigentes de escala nacional y departamental, quienes en cierto modo se encontraron impotentes frente a las dinámicas políticas locales; y quienes ante el desbordamiento de los hechos, tomaron medidas que en últimas, resultaron inoperantes. No obstante, no se puede dejar de lado la manipulación ejercida por aquellos políticos de Bogotá y de las capitales de los departamentos de Santander, Norte de Santander y Boyacá (Bucaramanga, Cúcuta y Tunja, respectivamente), interesados en que sus subalternos consiguieran una votación mayoritaria en cada región a cualquier precio, lo que les llevaba a una actitud, ya cómplice, o si no, permisiva respecto a los abusos cometidos por sus copartidarios en las regiones campesinas. En este orden de ideas, los nombres de las autoridades locales eran sugeridos de forma interesada e inescrupulosa por los directorios departamentales, liberales y conservadores, para que recayeran en los gamonales de su partido, o en miembros de sus respectivas clientelas. En dicho contexto, el poder del Estado en estas poblaciones y comarcas permanecía, en última instancia, bajo el control de los caciques, cuyo principal objetivo estuvo orientado a garantizar el triunfo electoral de su colectividad, para lo cual, emplearon con gran frecuencia el asesinato y el 
desplazamiento forzoso, no sólo en Boyacá, sino también en los departamentos de Santander del Norte y Santander del Sur, así como en menor medida, en otras regiones del país, durante este período.

La permisividad con los copartidarios trajo como consecuencia natural la impunidad, producto del sectarismo de alcaldes, jueces y policías de ambos partidos. No podemos olvidar, por otra parte, la intervención del clero en política a través del púlpito ${ }^{87}$ y el papel que desempeñó en este conflicto. A estos factores, se sumó el hecho de que la población civil estuviera armada y acostumbrada a dirimir sus diferencias políticas a través de altercados violentos (para lo cual, vale recordar la presencia en la memoria colectiva de los guerras civiles decimonónicas, artífices de lo que Miguel Antonio Caro denominó «odios heredados» ${ }^{88}$ ).

Estos mecanismos sectarios y violentos fueron ejercidos, por un lado, por parte de las autoridades liberales, con el fin de forzar adhesiones en un país que para entonces seguía siendo mayoritariamente conservador; o, al menos, para asegurar el triunfo electoral en localidades en donde los conservadores habían ejercido hasta entonces prácticas fraudulentas. De lo contrario, el éxito logrado en 1930 sería coyuntural y no podría prolongarse por mucho tiempo. Por otra parte, los conservadores contestaron a menudo de la misma forma violenta para tomar revancha por la pérdida del poder en 1930, o como respuesta a las agresiones de que fueron objeto, situación que llevó a la conformación de cuadrillas y autodefensas de ese partido. En este punto, vale la pena destacar el hecho de que el bandolerismo político ya estaba presente en ese entonces, y, por lo tanto, más que una respuesta anarquizada del campesinado de los años cincuenta y sesenta, ante las frustraciones de los proyectos políticos democráticos de las décadas anteriores -como plantean Sánchez y Meertens en referencia al bandolerismo del Frente Nacional ${ }^{89}$ - podría considerarse como un elemento característico de la relación represión y resistencia, propia de la violencia liberal-conservadora del siglo XX, en sus diferentes etapas. A la vez que, al constituirse en un elemento constitutivo de esta dinámica, invitaría a la indagación sobre la existencia de dicho fenómeno a partir de sus vínculos con los poderes políticos locales, en períodos precedentes del conflicto bipartidista; y, por supuesto, a destacar la prolongación de algunas de sus principales características, en actores de la violencia política posterior,

87 Memorándum sobre situación de los dos Santanderes, AGN, AA2, MG, S4ta, Justicia, Orden Público-Informes, Caja 1, Carpeta 3, fol. 80.

88 Orozco, 2003: 9.

89 Sánchez y Meertens, 2000: 52. 
también supeditados a poderes locales y nacionales, y dispuestos a la retaliación y a las acciones atroces sobre la población campesina.

Por último, una explicación de la Primera Violencia no puede dejar de lado aspectos como la pobreza y la falta de oportunidades provocados por el aislamiento de las zonas del nororiente, especialmente en los Santanderes, que desde luego repercutieron en el acuciante afán por el control del poder, el botín burocrático y el fácil acceso a la tierras abandonadas por el desplazamiento, motivaciones probablemente incrementadas en el contexto de la depresión económica del año treinta. A esto se sumó la proximidad de estas regiones con la frontera venezolana, lo que a su vez promovió el contrabando y el movimiento migratorio.

Cuando el político conservador santandereano Serrano Blanco quiso examinar las causas de la crisis, resumió los fenómenos que conjugados explicaban la situación del nororiente colombiano, en aquel entonces: «... la miseria económica, la invencible ignorancia, la humana retaliación, el afán burocrático, el egoísta individualismo, la ambición política, el fraude electoral $»^{90}$. Sin embargo, resulta esencial comprender el enfrentamiento bipartidista que nació y se desarrolló en el siglo XIX y se prolongó hasta los acuerdos del Frente Nacional (1958), en el contexto del conflicto entre tradición y modernidad, tal como lo proponen investigadores como François-Xavier Guerra, entre otros. Dicho enfoque permite interpretar mejor el peso de las dinámicas del poder local y, por ende, el rol del gamonalismo, el fraude electoral y la violencia, promovidos por los dos partidos, como resultado no sólo de las particulares ambiciones; sino también, de una concepción cultural excluyente de la política, en pugna con la propuesta pluralista y consensual del ideario liberal ilustrado. Estos diversos factores, en los que se entretejen condiciones estructurales y apetitos personales, en su conjunto, permiten entender mejor los vínculos y la actuación de los diversos actores de la violencia bipartidista de estos años: jefes políticos nacionales, regionales y locales; alcaldes y jueces, ejército, policías, autodefensas y bandoleros; $y$, desde luego, la inerme población campesina -hombres, mujeres y niños- trágicamente convertida en la principal víctima de esta conflagración.

90 Serrano Blanco, 1949: 16. Citado en Henderson, 2006: 269 y 270. 


\section{BIBLIOGRAFÍA}

Abel, Christopher, Política, Iglesia y partidos en Colombia: 1886-1953, Bogotá, Universidad Nacional de Colombia, 1987.

Acuña, Olga Yanet, "Jornadas y fraude electoral en el departamento de Boyacá. 19301950", Isabel Cristina Bermúdez (comp.), Poder regional y discurso étnico, Cali, Grupo Región, Universidad Pablo Olavide, Universidad del Valle, 2003: 303-333.

Acuña, Olga Yaneth, "Juego político y acción militar durante la República Liberal, una forma de violencia institucional”, Memorias del XII Congreso Colombiano de Historia, CD Rom, 2006.

Acuña, Olga Yaneth, "La militarización de la política. Una forma de violencia institucional, 1946-1953", Humaniverso, 1 (Santiago de Querétaro, 2008): 1-30.

Atehortúa, Adolfo, Construcción del ejército nacional en Colombia, 1907-1930: reforma militar y misiones extranjeras, Bogotá, La Carreta, 2009.

Buve, Raymond, "Caciquismo, un principio de ejercicio de poder durante varios siglos", Relaciones: estudios de historia y sociedad, XXIV/96 (Zamora, 2003): 19-39.

Cáceres Mateus, Sergio Armando, "El presbítero Daniel Jordán Contreras en el nororiente colombiano, 1930-1948”, Historia y Sociedad, 25 (Bogotá, 2013): 187127.

Calderón Rodríguez, Ivonne Vanesa, "Piedecuesta, Floridablanca y Bucaramanga: escenarios de intransigencia católica en Santander, 1930-1931", Historia y Sociedad, 25 (Bogotá, 2013): 157-185.

Costa, Joaquín, Oligarquía y caciquismo como la forma actual de gobierno en España: urgencia y modo de cambiarla, Úbeda, Asociación Cultural Ubetense, 2012.

Deas, Malcom, "Algunas notas sobre la historia del caciquismo en Colombia", $R e$ vista de Occidente, 127 (Bogotá, 1973): 118-140.

Deas, Malcom, "Algunas notas sobre la historia del caciquismo en Colombia", Del poder y la gramática y otros ensayos sobre historia, política y literatura colombianas, Bogotá, Norma, 2006: 209-233.

Figueroa, Helwar, "Clérigos y violencia en el norte de Boyacá. 1930-1946", Andrés Eduardo González (ed.), Diversidad y dinámicas del cristianismo en América Latina, Bogotá, Editorial Bonaventuriana, 2007: 355-396.

Gómez, Laureano, Comentarios a un régimen, Bogotá, Editorial Minerva, 1934.

Guerra, François-Xavier, "Los orígenes socioculturales del caciquismo", Anick Lempérière, y Georges Lomné (comps.), Figuras de la modernidad. Hispanoamérica, siglos XIX y XX, Bogotá, Externado de Colombia, Taurus, 2012: 85-106. 
Guerrero, Javier, Los años del olvido: Boyacá y los orígenes de la violencia, Bogotá, Tercer Mundo, Universidad Nacional, Iepri, 1991.

Guerrero, Javier, Los años del olvido: Boyacá y los orígenes de la violencia, Tunja, Universidad Pedagógica y Tecnológica de Colombia, 2007.

Guerrero Javier, "Región: ilegalidad y violencia en el caso de las 'guerras de las esmeraldas"”, Javier Guerrero y Olga Yaneth Acuña (comp.), Boyacá, región y conflicto, Medellín, La Carreta, 2008: 111-135.

Gutiérrez, Rufino, Monografias, vol. 1, Bogotá, Imprenta Nacional, 1920.

Guzmán, Germán, La Violencia en Colombia: parte descriptiva, Cali, Progreso, 1968.

Henderson, James, La modernización en Colombia: los años de Laureano Gómez, 1889-1965, Medellín, Universidad de Antioquia, 2006.

Hilarión S, Alfonso, Balas de la Ley, Bogotá, Editorial Santafé, 1953.

Horgan, Terrence, The liberals come to power in Colombia, por debajo de la ruana: a study of the Enrique Olaya Herrera administration, 1930-1934, tesis maestría/ doctorado en Historia, Vanderbilt University, 1983.

Melo, Jorge Orlando, "Caciques y gamonales: perfil político", Revista Credencial Historia, 103 (Bogotá, 1998): 4-5.

Ocampo López, Javier, Las ideas de un día: el pueblo mexicano en la consumación de la independencia, México, Colegio de México, 1969.

Oquist, Paul, Violencia, conflicto y política en Colombia, Bogotá, Banco Popular, 1978.

Orozco, Iván, La postguerra colombiana. Divagaciones sobre la venganza, la justicia y la retaliación, South Bend, Kellog Institute for International Studies, 2003.

Palacios, Marco, "La gobernabilidad en Colombia. Aspectos históricos", Análisis Político, 29 (Bogotá, 1996): 1-23.

Pinzón Lewin, Patricia, El ejército y las elecciones, Bogotá, Cerec, 1994.

Posada Carbó, Eduardo, "Elecciones y guerras civiles en la Colombia del siglo XIX: la campaña presidencial de 1875", El desafio de las ideas. Ensayos de historia intelectual y política en Colombia, Medellín, Eafit, 2003: 201-240.

Quintero Restrepo, León David, “Los 'Pájaros' del Valle del Cauca”, Revista Estudios de Derecho, LXV/145 (Medellín, 2008): 243-258.

Restrepo, Juan Camilo y Betancur, Luís Ignacio, Conflicto amazónico, 1932-1934, Bogotá, Villegas editores, 2001.

Rodríguez Barrera, Óscar J. y Cazorla Sánchez, Antonio, "Hoy Azaña, mañana... Franco. Una microhistoria de caciquismo en democracia y dictadura. Berja, Almería, 1931-1945”, Hispania, Revista Española de Historia, LVIII/ 229 (Madrid, 2008): 471-502. 
Sánchez, Gonzalo y Meertens, Donny, Bandoleros, gamonales y campesinos: el caso de la Violencia en Colombia, Bogotá, Áncora editores, 2000.

Serrano Blanco, Manuel, Las viñas del odio, Bucaramanga, Imprenta Departamental, 1949.

Vázquez Piñeros, María del Rosario, "La Iglesia y la Violencia Bipartidista en Colombia (1946-1953): análisis historiográfico", Anuario de Historia de la Iglesia, XVI (Pamplona, 2007): 309-334.

Vázquez Piñeros, María del Rosario, Iglesia y Estado en Colombia durante el gobierno de la Concentración Nacional: clero, partidos y violencia, 1929-1934, tesis doctorado en Historia, Universidad del País Vasco, Vitoria-Gasteiz, 2012.

Vázquez Piñeros, María del Rosario, "La Iglesia y las elecciones de 1930: Un conflicto entre tradición y modernidad en el marco del proceso de secularización en Colombia", Anuario de Historia de la Iglesia, XXIII (Pamplona, 2014a): 433-458.

Vázquez Piñeros, María del Rosario, "Anticlericalismo y Primera Violencia en la Diócesis de Nueva Pamplona, Colombia (1930-1934): clero, políticos, jueces y policías", Hispania Sacra, LXVI/133 (Madrid, 2014b): 263-285.

Fecha de recepción: 21 de agosto de 2014.

Fecha de envío de las modificaciones: 28 de marzo de 2015.

Fecha de aceptación: 7 de abril de 2015.

\title{
Local political leaders and mayors: \\ Institutional and non-institutional power in the First Violence (Colombia, 1930-1934)
}

\begin{abstract}
By consulting and collating periodical and documentary sources -of both a civil and ecclesiastical nature- this article analyses the relationship that local political leaders (gamonales) and civil authorities established with armed institutional and illegal non-institutional groups. By exerting coercion and persecution, both leaders and civilian authorities served as a means for their political party to achieve electoral victory. This relationship made them key architects of the first stage of the Liberal-Conservative Violence, initiated under the government of Colombian President Enrique Olaya Herrera (1930-34).
\end{abstract}

KeY WORDS: Colombia; violence; local administration; elections; armed forces. 